\title{
Conceptual Bases of Intellectual Management System of Innovative Technoparks
}

\author{
Alovsat Garaja Aliyev ${ }^{a^{*}}$, Roza Ordukhan Shahverdiyeva ${ }^{\mathrm{b}}$ \\ ${ }^{a, b}$ Institute of Information Technology, Azerbaijan National Academy of Sciences, Baku, Azerbaijan AZ1141, \\ Azerbaijan Republic, Baku, B.Vahabzade str.9
}

\begin{abstract}
In the article development issues of conceptual bases of the establishment of intellectual management system of innovative technoparks are viewed. Creation necessity of technoparks has been indicated, their management features and indicators have been defined. Management mechanisms of technoparks have been clarified. Conceptual model of management of technoparks has been developed. Conceptual structures of management system on the basis of intellectualizing features of management have been offered.
\end{abstract}

Index Terms: Innovative structure, high-tech park, management problems, management indicators, technoparks management system, management intellectualization.

(C) 2017 Published by MECS Publisher. Selection and/or peer review under responsibility of the Research Association of Modern Education and Computer Science.

\section{Introduction}

Modern economy develops on the basis of innovations. In this regard many world countries develop development strategies of their national economies.

In "Azerbaijan 2020: Vision of the Future" Development Concept [1], as well as the National Strategy for the development of the Information Society [2] it is spoken about development of new management mechanisms towards to strengthen reciprocal relations between the fields of science, education and production, the establishment of innovation centers, technological complexes, technoparks and business incubators, and issues of their activity organization. In order to develop innovative economy in Azerbaijan, Sumgait industrial and chemical technology park, Ministry of Communications and High Technologies "High Technologies Park" in Baku, Science and Technology Park in Azerbaijan National Academy of Sciences (ANAS), Eco-industrial park in Balakhani, agro and other high tech parks in regions have been established to form manufacturing of competitive, innovative products or service with high export potential [3]. Both internal factors such as progress, capital and environmental sustainability, and some external factors influence activity planning and * Corresponding author. Ph.D. in economics Alovsat Aliyev, Head of department of the Institute of Information Technology of Azerbaijan National Academy of Sciences, Baku, Azerbaijan. phone: (994 12)5397226;

E-mail: alovsat_qaraca@mail.ru, shahverdiyevar@gmail.com 
management of these technoparks [4].

Management of technoparks are related to several problems. Planning of development in technoparks, activity organization, motivation of staff, organization of governmental control, etc. are included in those problems [5]. The necessity for determination of main management parameters in technoparks activity, development of its management model and intellectual control system has made the continuation of researches in this area indispensable.

\section{Management Features of Modern Innovative Technoparks}

General principles of management of technoparks activity are regulated on the basis of the legislation about enterprises. After establishment of technoparks certain measures are being implemented in order to ensure its management and development. The competent authority for the establishment of technoparks implements following functions: 1)to participate in the formation of governmental politics in the field of establishment and activity of technoparks, 2)to help responsible company with the organization of activity in technoparks, 3)to form innovative and legal acts that regulate technopark activity, 4)to select management operator, 5)to regulate technopark activity, 6)to prepare annual report about technopark activity and so on.

For the management of technoparks, proper management system should be established. This system must be formed according to organizational and economical structure and as well as purpose ad duties of technoparks [5-8]. According to the content, functions of the management system consist of functions such as accounting, analysis, planning, organization, forecasting, connection and control. Concrete tasks are being implemented in accordance with each stage of the management. Following tasks are included in such tasks: 1.establishment of favorable condition for the formation of supporting system of innovative activity, activity of residential companies, implementation of scientific-research and experimental- constructor works, 2.consulting, engineering, technical, technological, information and other services for innovation enterprises, 3.market research, marketing services for related enterprises, 4.revealing innovative product and accompanying of them, 5.development of intellectual information system for supporting decision-making, assistance to the development of innovation orders and investment projects on the preferential privileges for technopark residents, assistance to attracting investment for the establishment of the development of innovation business and science-intensive manufacture, to achieve effective organization of scientific-educational-industrial relations, to create modern information structure, selection of factors that influence effectiveness of technopark activity, revealing internal potential and external environment that help to increase effectiveness of technopark, determination of application conditions of effectiveness strategy based on balanced indicators concept in technoparks and so on.

\section{Management Indicators of Innovative Technoparks Activity}

On the basis of systematization of technoparks activity experiment, its management indicators can be determined. Effective management of technoparks is also evaluated on the basis of that kind of indicators. Following indicators are included in such indicators: 1)tax and customer preferences in technoparks, 2)scientific-innovative and educational activity of technoparks, 3)scientific-technical, technological and resource potential, 4)governmental regulation mechanisms of development of innovative strategies, 5)financial and investment sources, 6)staff potential, 7)recognition level of technopark residents, higher education and scientific research institutions, 8)infrastructure, technical, social and information provision of technoparks, 9)direct interest of scientific research and education institutions, compatibility of specialization of technopark in the priorities of region policy, sustainable partnership with industrial companies, advanced practice in the field of commercialization of researches and technologies, balanced activity plan of technopakr and so on. These indicators and relationship among them must be taken as an essential part in the development of effective management structure. 


\section{Management Mechanisms and Features of Technoparks}

Management mechanisms and tools of technoparks are consisted of a set of management decision-making procedures and rules, and they have essential impact on the subjects activity managed in technoparks [9-12]. In order to achieve main goals of technoparks, the organization of management processes such as planning, organization, motivation, control, should be implemented. According to activity purposes and issues, property management of technoparks, as well as implementation of its organizational activity are implemented by management company. Management company contributes to the development of residents' business by gathering current and perspective functions of technopark managers, and serves proper business-services to them. Management company also involves scientific and technological innovative enterprises to technoparks, place them and serve to them. Following stages can be included in management of technoparks: 1)analysis and monitoring of current state of managed system, 2)its development and forecasting, 3)ambitiousness, 4)planning, 5)distribution of resources and functions, 6)stimulation, 7)operative management and control, 8)analysis of changes $[13,14]$.

It should be noted that, in any system, including technoparks there must be management mechanisms for the efficient management. It should be considered that currently enough experience has been obtained which allows implementation of management functions such as control, motivation, organization, planning in accordance with management stages in the development and application field of management theory.

In practice, the various governing bodies of technoparks have been established. Management structure of technoparks are like below: 1)technopark management, board of directors, 2)scientific and technical council, 3)financial and economical block, 4)intellectual property service, 5)innovative projects center, 6)production and innovation institutions and companies, 7)scientific and educational complex, 8)business incubator, 9)technopark units, 10)service, 11)marketing and commercialization.

\section{Conceptual Model of Management of Technoparks}

Effective management of technoparks activity creates necessity for the development of its specific conceptual model beforehand. The establishment of such a model should be based on modern scientifictechnological and innovative approach (Fig. 1).

This model, in general case, is the harmonious combination of social-economical purposes of technopark, management system, requirements of innovation-investment projects, commercialization mechanisms of the results of scientific researches, organizational principles of participant elements and production [14, 15]. The presented picture provides information about list of submodels, their content and main components, which are necessary for the effective management of technoparks.

\section{Intellectualization Features of Management}

Following areas are preferred in the development concept of technoparks to increase effectiveness of technopark activity: 1)consideration of development prospects in produced goods and services, 2)application of intellectual systems in determination of innovation and scientific research areas, modernization of enterprise, development and management of database, 3)development of mobile management structure of eneterprise, 4)increasing the role of the human factor in increasing the efficiency of the enterprise; 5)consideration of innovative services aimed at the needs of enterprise customers; 6.the using of advanced technologies, ICT for development of enterprise, the role of highly qualified specialists and scholars, using of technological opportunities such as modeling, stimulation, forecasting, etc. 


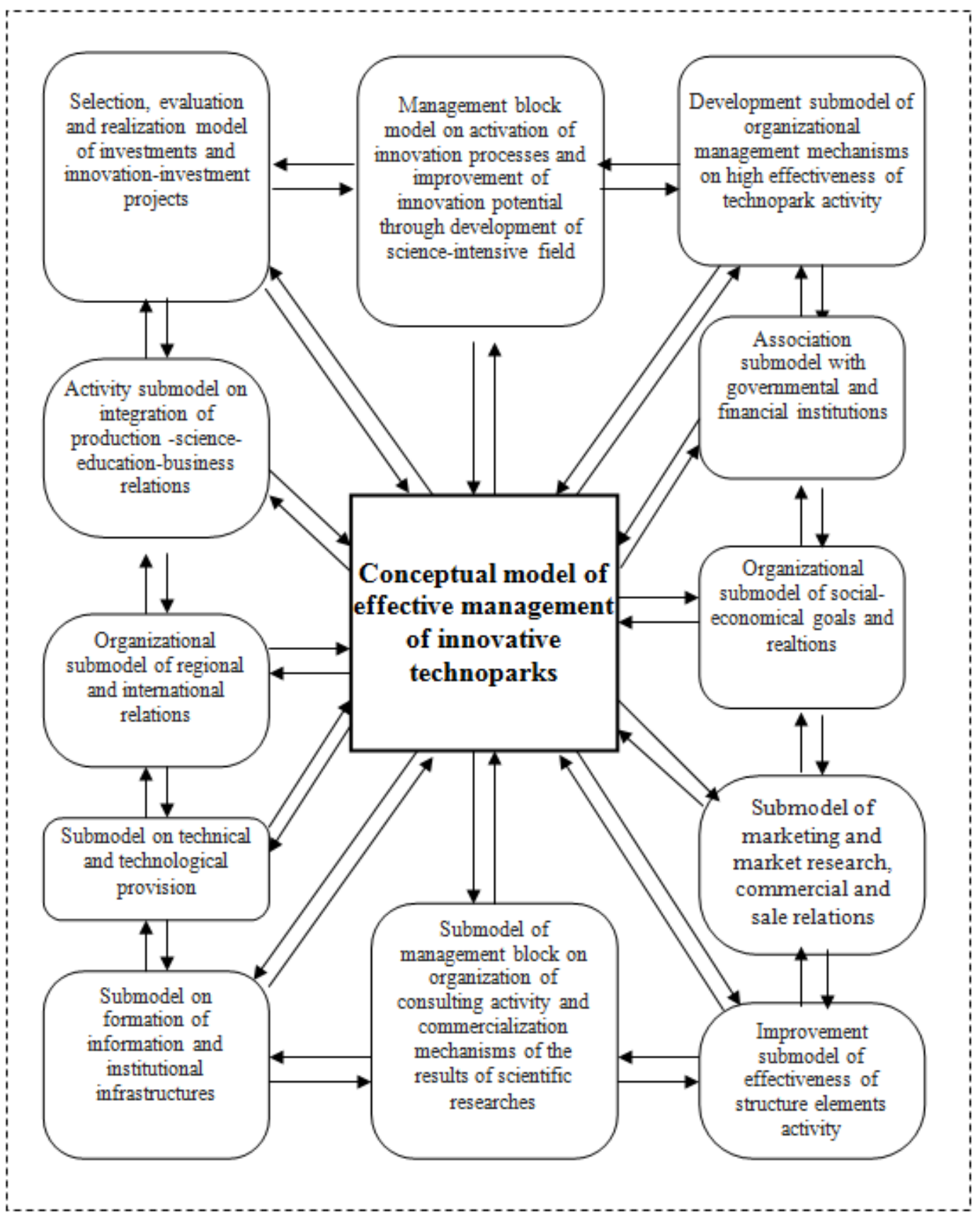

Fig.1. Conceptual Model of Effective Management of Innovative Technoparks

Prospective speheres of the application of intellectual systems in economy are below: 1) production management, 2) internal planning and forecasting of production and enterprise, 3) marketing and sales management, 4) financial management, 5) the risk-management 6)banking, 7)commercial and others. Intellectual systems are classified according to different features. Establishing process of intellectual systems 
such as neural networks and expert systems are different. According to application scope of intellectual systems, they are divided into systems that are aimed at adressing the economical issues, prepared for marketing researches and desgined for decision-making in the legal field. According to solving the issues intellectual systems are divided into system that advise, test and diagnose. Currently, intellectual systems are virtually used in all areas. In classification of intellectual information systems, their application areas, autonomy level, dependency on knowledge base or information systems, reciprocal interaction with objects, adoptivity, presentation model of knowledge should be considered. By taking afformentioned qualifications and responsibilities, intellectualization contours of management of technoparks activity can be given as a set of interconnected blocks (Fig. 2).

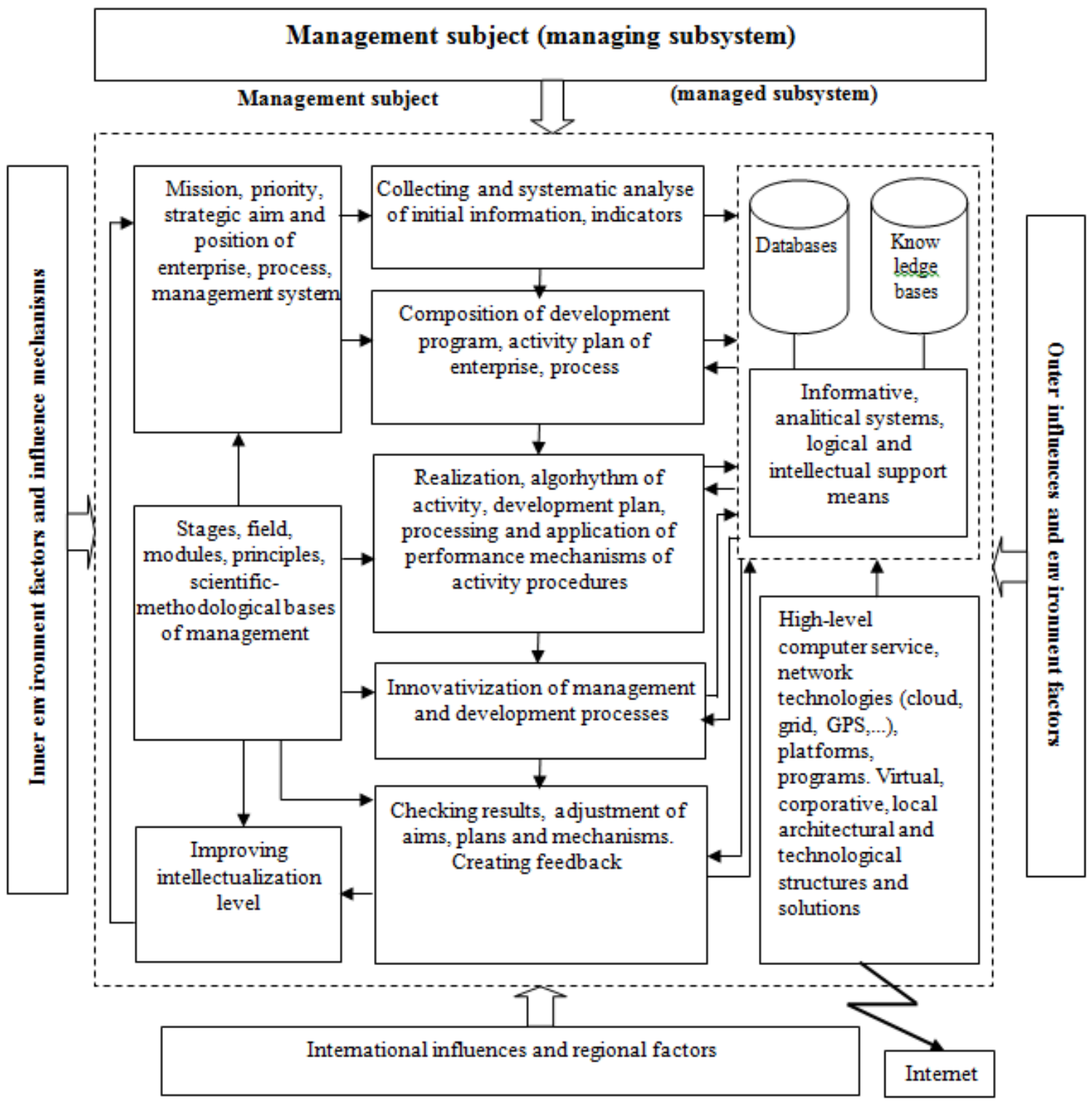

Fig.2. Conceptual Structure of Intellectual Management System of the Innovative Technoparks 


\section{Conclusion}

Economy that based on new age development strategy is formed by the innovative structures, as well as technoparks. In the third millennium the establishment of information community depends on the formation and development of an economy based on knowledge and innovation. In modern age, the economic development of the countries gives impetus to the development of science-intensive areas, as well as technological innovations, new technologies. The use of science intensive technologies has caused to innovation-oriented economical development as a brand new area.

Management feature of innovative technoparks requires full management of innovations in technoparks as well as main deveopment areas of projects and management of investments. At the same time technopark as a business structure serves a wide range of professional service to innovative resident companies. Moreover technopark organize efficient management process of real estate property. The above-mentioned aspects require the establishment of efficient and intellectual management system. As a result of such management, balanced management system policy in innovation area, efficient use of property are implemented.

It can be noted that realization of creation suggestion of intellectual management system conception of innovative technoparks will allow increasement of activity efficiency and science-intensive development of non-oil sector in high tech base.

\section{Reference}

[1] Development Concept "Azerbaijan - 2020: outlook for the future". Baku, 2012, www.president.az.

[2] Azerbaijani President's decree on the approval of the National Strategy for Information Society Development in the 2014-2020 period. Baku, 2014, www.president.az.

[3] Decree of the President of the Republic of Azerbaijan on the establishment of the High Technologies Park, Baku, 2012. www.president.az.

[4] Muhammad U.W. Factors for Science Park Planning, WTR 2014;3, pp 97-108.

[5] Alguliyev R.M., Aliyev A.G., Shahverdiyeva R.O. High Techno-Parks in the economy of Azerbaijan and their management problems. ICIESM 2014: XI International Conference on Innovation, Entrepreneurship and Strategic Management. Osaka, Japan, 2014. P.426-428.Byung-Joo Kang. Exploring Governance Models of Science \& Research Parks and Related Organizations, World Technopolis Review, 2014; 3: pp. 39-54.

[7] Huang S. P. A Study on the Effect of Innovative Management on Managerial Performance, "Actual Problems of Economics, 2012, №6 (132), pp.475-485.

[8] Wan Ting. Study on the Scientific Research Group Management of Chinese High Technology Enterprises from the Perspective of Knowledge Transfer, I.J. Education and Management Engineering 2012, 3, 57-63.

[9] Aliyev A.G., Shahverdiyeva R.O., Аббасова B.A. The conceptual basis for the development of innovative technoparks management mechanisms. Українська наука: минуле, сучасне, майбутнє, Тернопільський національний економічний університет МОН України, 2014, №2, pp.14-27.

[10] R.M.Alguliyev, A.G.Aliyev, R.O.Shahverdiyeva. Development of information support systems for management of innovative structures. The 8th IEEE International Conference on Application of Information and Communication Technologies (AICT2014). Astana, 2014. pp. 378-382.

[11] W.Huihui. Study on the Innovation of Industrial Park's Operating Mechanism. //Product Innovation Management (ICPIM), 2011 6th International Conference. IEEE, 2011, pp. 240-243.

[12] Novikov D.A. Management methodology. - M.: Librokom. Moscow. 2011. pp. 128.

[13] Nagy K.H. Managing Change and Innovation in Government. Journal Innovation, Technology, and Knowledge Management, 2011, pp.143-198.

[14] Fikirkoca, A. and Saritas O. Foresight for science parks: the case of Ankara University, Technology 
Analysis \& Strategic Management, 2012, 24(10), pp.1071-1085.

[15] Wang Qi-Ming, Zhao Xi-nan, Zhang Li-li. A Novel Thought and Method of University Evaluation, I.J. Education and Management Engineering, 2013, 2, 59-65.

\section{Authors' Profiles}

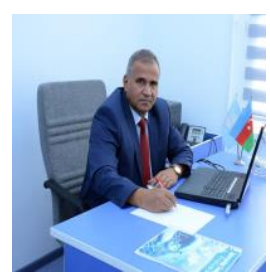

Ph.D. in economics, ass. professor Alovsat Aliyev (born January 8, 1956). Head of department of the Institute of Information Technology of ANAS, Baku, Azerbaijan. He has a total number of 74 scientific articles and 5 books. Alovsat Aliyev continues to conduct scientific-research works and deals with issues such as characteristics of ICT application in economical processes and management authorities, information problems in socialeconomical systems, scientific-theoretical basics of formation of information society, determination of demonstrative systems in ICT field, research of reasons of establishment of digital differences in the society, study economical basics, problems of informatization of humanitarian fields, humanitarian aspects of ICT.

Areas of interest: innovative information and knowledge economy, technoparks, green economy, computers and information science, econometrics.

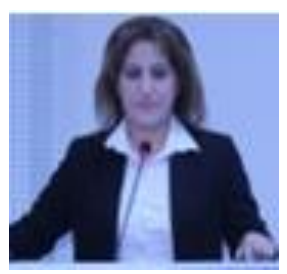

Roza Ordukhan Shahverdiyeva: Senior scientist of Institute of Information Technology of ANAS, Baku, Azerbaijan.

She has a total number of 18 scientific articles. Her articles dedicated to actual ICT problems are regularly published in various scientific journals and newspapers.

Areas of interest: information systems, process of innovation, technoparks, management

How to cite this paper: Alovsat Garaja Aliyev, Roza Ordukhan Shahverdiyeva,"Conceptual Bases of Intellectual Management System of Innovative Technoparks", International Journal of Education and Management Engineering(IJEME), Vol.7, No.2, pp.1-7, 2017.DOI: 10.5815/ijeme.2017.02.01 